\title{
In vitro culture of ovine mammary gland cells expressing beta-lactoglobulin and beta-casein
}

\section{Células da glândula mamária ovina cultivadas in vitro expressam beta-lactoglobulina e beta-caseina}

\author{
Mariana Ianello GIASSETTI ${ }^{1}$; Flavia Regina Oliveira de BARROS ${ }^{1,2}$; Camilla Mota MENDES ${ }^{1}$; \\ Marcelo Demarchi GOISSIS ${ }^{1}$; Fernanda Sevciuc MARIA ${ }^{1}$; Adriano Felipe Perez SIQUEIRA ${ }^{1}$; Renata SIMÕES ${ }^{1,3}$; \\ Mayra Elena Ortiz Avila ASSUMPÇÃO ${ }^{1}$; José Antônio VISINTIN ${ }^{1}$ \\ ${ }^{1}$ Universidade de São Paulo, Faculdade de Medicina Veterinária, Departamento de Reprodução Animal, São Paulo - SP, Brazil \\ ${ }^{2}$ The Hospital for Sick Children, Toronto - ON, Canada \\ ${ }^{3}$ Universidade Federal do ABC, Centro de Ciências Naturais e Humanas, Santo André - SP, Brazil
}

\begin{abstract}
The expression of milk proteins in vitro is essential to exploit the mammary gland cells as a biological model. Enzymatic tissue disaggregation has been widely used to establish mammary cell culture, but its effect in long-term ovine mammary cell culture is not completely elucidated. This study aimed at comparing mechanical/enzymatic and mechanical dissociation methods to establish ovine mammary cell culture. We compared cellular differentiation induced by lactating ewe serum or fetal bovine serum based on the gene expression levels of milk proteins (beta-lactoglobulin, alpha s1-casein, and betacasein). Mechanically dissociated cells were positive immunostaining for cytokeratin 8.13 , such as mammary epithelial cells. These cells are responsible for milk protein expression and they are low immunostaining for vimentin, mesenchymal marker. Mechanical/enzymatic dissociation cells were positive for vimentin. The fastest cell growth (cell/hour) was observed in the mechanical dissociation group cultured with $10 \%$ fetal bovine serum medium. Mechanically and mechanically/enzymatically derived cells were able to express beta-casein and beta-lactoglobulin, but not alpha s1-casein. The relative expression of beta-lactoglobulin was not affected by the tissue dissociation method or culture media, beta-casein relative expression was down regulated in mechanically dissociated cells cultured in the presence of lactating ewe serum, $(\mathrm{P}=0.019)$. Beta-casein relative expression was also down regulated in mechanically/enzymatically dissociated cells cultured with fetal bovine serum $(\mathrm{P}=0.021)$. In the present conditions, we conclude that mechanical dissociation followed by culture with $10 \%$ of fetal bovine serum was the most efficient method to induce milk proteins' mRNA expression by ovine mammary epithelial cells in vitro.
\end{abstract} Keywords: Mammary cell culture. Milk proteins. Beta-casein. Ovine.

\section{Resumo}

A expressão in vitro de proteínas do leite é essencial para explorar as células da glândula mamária como um modelo biológico. A desagregação tecidual via enzimática é amplamente utilizada para o estabelecimento cultivo de células mamárias. No entanto, seu efeito a longo prazo no cultivo de células da glândula mamária ovina ainda não é bem elucidado. Este estudo tem como objetivo comparar dois métodos de dissociação tecidual, mecânico/enzimático e mecânico, para estabelecer cultivo celular de glândula mamária ovina. A indução da diferenciação celular, por adição de soro de ovelha lactante ou soro fetal bovino, foi avaliada pelos níveis de expressão de proteínas do leite (beta-lactoglobulina, alpha s1-caseína e beta-caseína). Células mecanicamente dissociadas foram positivamente marcadas para a presença de citoqueratina 8.13, marcador para células epiteliais mamárias. Essas células são as responsáveis pela produção das proteínas do leite e são pouco marcadas para a presença de vimentina, marcador para células de origem mesenquimal. Já as células obtidas da dissociação mecânica/ enzimática foram positivamente marcadas para presença de vimentina. A maior velocidade de crescimento (células/hora) foi observado para o grupo com dissociação mecânica cultivado em meio com $10 \%$ de soro fetal bovino. As células obtidas tanto da dissociação mecânica quanto mecânica/enzimática foram capazes de expressar beta-lactoglobulina e beta-caseína, mas não alfa s1-caseína. A expressão relativa de beta-lactoglobulina não foi afetada pelo método de dissociação ou meio de cultivo. A expressão relativa da beta-caseína foi negativamente regulada para células mecanicamente dissociadas e cultivadas na presença de soro de ovelha lactante $(\mathrm{P}=0,019)$. A expressão relativa da beta-caseína também foi negativamente regulada para células dissociadas de forma mecânica/enzimática e cultivadas com soro fetal bovino $(\mathrm{P}=0,021)$. Nas condições do presente estudo, concluímos que o método de dissociação mecânica seguido pelo cultivo em meio com $10 \%$ de soro fetal bovino foi o método mais eficiente para induzir a expressão mRNA de proteínas do leite por células epiteliais mamárias ovinas in vitro. Palavras-chave: Cultura de célula mamária. Proteínas do leite. Beta-caseína. Ovelha. 
Correspondence to:

Mariana Ianello Giassetti

Universidade de São Paulo, Faculdade de Medicina Veterinária

e Zootecnia, Departamento de Reprodução Animal

Av. Orlando Marques de Paiva, 87

CEP 05508-270, São Paulo, SP, Brazil

e-mail: mariana.giassetti@usp.br

Received: $17 / 01 / 2017$

Aproved: 03/05/2017

\section{Introduction}

The mammary gland is a very attractive biological model to study protein expression and synthesis, cellular proliferation and differentiation, organogenesis, and oncogenesis (ILAN et al., 1998). Cell lines derived from the mammary gland could be used as an in vitro model to investigate molecular factors and pathways involved in the formation, development, differentiation, and function of the mammary gland. In this way, establishment of a mammary cell culture is crucial for the development of cellular physiology studies.

The number of in vitro studies for mammogenesis and lactation in domestic animals are limited when compared to those in rodents. Only a few mammary gland cell lines have been established for domestic species such as bovine (LAMMERS et al., 1999; MATITASHVILI; BAUMAN, 1999; ROSE et al., 2002; HU et al., 2009), swine (SUN et al., 2006), and ovine (DÜCHLER et al., 1998; ILAN et al., 1998). There are strong biological differences between rodent and ruminant lactation, mainly regarding milk composition and effect/response of regulatory factors on mammary cells (JENNESS; SLOAN, 1970; GREEN; PASTEWKA, 1976). Therefore, experimental models based on rodent cells have limited application in other species, such as ovine (WHEELER et al., 1995). Sheep and cows express the same milk proteins but sheep milk contains higher total of milk proteins (PARK et al., 2007). Alpha s1-casein (CSN1S1), alpha-S2 casein (CSN1S2), beta-casein (CSN2), and kappa-casein (CSN3) are the major proteins in sheep milk (76-83\% of total proteins), but the major whey protein is beta-lactoglobulin (BLG) (PARK et al., 2007).

One of the main ovine mammary cell lines described in the literature is NISH (DÜCHLER et al., 1998; ILAN et al., 1998). NISH was isolated by Trypsin/Collagenase digestion (ILAN et al., 1998) and comprised heterogeneous cell populations that included fibroblast-like cells and epithelial cells. The enzymatic digestion method, which destroys the extracellular matrix, has been widely used for ovine mammary-cell isolation (DÜCHLER et al., 1998;
ILAN et al., 1998). While Trypsin allows the most complete cell disaggregation, Collagenase causes less harmful, though incomplete disaggregation. The total number of disaggregated cells provided by mechanical method is lower than the one obtained by enzymatic digestion (FRESHNEY, 1994), and ruminant mammary cell isolation and culture has not been widely studied. In mice, direct cell isolation from mammary tumors using Collagenase increasse the number of cells recovered. However, most cells that attach and grow in primary culture are often gradually overwhelmed by fibroblast overgrowth (PEI et al., 2004).

The mechanical disaggregation method could be used for monitoring the cell growth and identifying fibroblast overgrowth (PEI et al., 2004), influencing the cell heterogeneity in a long-term mammary cell culture. However, the effect of different cell-isolation methods on long-term cell culture or milk protein gene expression has not been thouroughly studied. Thus, we aimed to compare two methods of tissue disaggregation, mechanical plus enzymatic (MED) or mechanical only (MD), in order to establish long-term ovine mammary cell cultures. We also verified the gene expression of $B L G, C S N 1 S 1$, and CSN2 after milk protein expression induction by FBS or lactating ewe serum (LES) at passage twelve (P12).

\section{Materials and Methods}

All chemicals were supplied by Sigma Chemical Company (St. Louis, Missouri, USA), unless otherwise stated. All procedures were approved by the Bioethics Committee for Use of Animals of the College of Veterinary Medicine and Animal Science of University of São Paulo.

\section{Establishment of cell culture from mammary parenchyma biopsies}

Mammary biopsy was obtained from gland parenchyma of a 90-days-pregnant ewe after anesthesia. After mechanical mincing, fragments were divided into two groups, MED and MD. The fragments from the MD group were plated on $60 \mathrm{~mm}$ Petri dishes with DMEM medium (Life Technologies, Carlsbad, California, USA) with 10\% (v/v) of FBS (Gibco $\left.{ }^{\oplus}\right), 50 \mu \mathrm{g} / \mathrm{mL}$ of gentamicin, $100 \mathrm{UI} / \mathrm{mL}$ of penicillin, $100 \mu \mathrm{g} / \mathrm{ml}$ of streptomycin solution, $10 \mu \mathrm{L} /$ $\mathrm{mL}$ of non-essential amino acids solution, and $5 \mu \mathrm{L} / \mathrm{mL}$ of Fungizone (Life Technologies, Carlsbad, California, USA). The tissue for the MED group was further ground in a tea strainer and then incubated for $45 \mathrm{~min}$ at $37^{\circ} \mathrm{C}$ in TCM-199 Hepes medium (Life Technologies, Carlsbad, California, 
USA) with $0.02 \%(\mathrm{w} / \mathrm{v})$ Trypsin, $1 \%(\mathrm{w} / \mathrm{v})$ Collagenase A, $1 \%(\mathrm{w} / \mathrm{v})$ Hyaluronidase, and homogenized every $5 \mathrm{~min}$. After protease activity blocking with DMEM containing $10 \%(\mathrm{v} / \mathrm{v})$ FBS, the cell suspension was centrifuged at $84 \mathrm{x} \mathrm{g} / 5 \mathrm{~min}$, the pellet was resuspended in culture medium, and plated on $60 \mathrm{~mm}$ Petri dishes.

Both groups were cultured for 7 days at $37^{\circ} \mathrm{C}$ in saturated humidity atmosphere with $5 \%(\mathrm{v} / \mathrm{v})$ of $\mathrm{CO}_{2}$. After attaining semi-confluence, the cells were passaged by enzymatic digestion with $0.01 \%(\mathrm{w} / \mathrm{v})$ Trypsin, split at a 1:2 ratio and plated on new $60 \mathrm{~mm}$ dishes. This procedure was repeated until passage three (P3), when cell concentration and viability were assessed by Trypan Blue solution exclusion method $(5 \mathrm{mg} / \mathrm{mL})$ and cells were cryopreserved $\left(1 \times 10^{6}\right.$ viable cells $/ \mathrm{mL}$ ) in DMEM medium with $20 \%(\mathrm{v} / \mathrm{v}) \mathrm{FBS}$, $10 \%(\mathrm{v} / \mathrm{v}) \mathrm{DMSO}$, and $10 \mu \mathrm{g} / \mathrm{mL}$ of gentamicin at $-80^{\circ} \mathrm{C}$ using the Mr. Frosty container (Nalgene ${ }^{\oplus}$, Waltham, Massachusetts, USA), and then placed into liquid nitrogen at $-196^{\circ} \mathrm{C}$. Approximately $3 \times 10^{6}$ cryopreserved cells from both groups were thawed and plated on $100 \mathrm{~mm}$ Petri dishes. Cells were cultured until P12, being cryopreserved again at passage eight (P8). Throughout cell culture, morphology was analyzed and representative images were obtained by optical microscopy (Olympus IX81) under 400x magnification by Image Plus Software (Olympus).

\section{Induction of differentiation by lactating ovine serum}

At P12, differentiation of mammary gland cells was induced with lactating ewe serum (LES) that contains lactogenic factors for either MD or MED groups and compared to FBS as control. LES was obtained by pooling inactivated serum $\left(56^{\circ} \mathrm{C}\right.$ for $\left.1 \mathrm{~h}\right)$ from Santa Ines ewes after $15(\mathrm{n}=3), 30(\mathrm{n}=3)$, and $45(\mathrm{n}=3)$ days of lactation. The differentiation of ovine mammary cells was performed in 24 -well plates containing $1 \times 10^{5}$ viable cells per well that were cultured until reaching semi-confluence. Culture media was partially changed daily. After 7 days, cell samples ( $2 \times 10^{5}$ viable cells were then collected and stored at $-196^{\circ} \mathrm{C}$ for total RNA extraction. Differentiation of mammary cells was evaluated by relative expression of milk proteins genes from both groups, MD and MED, after the treatment with $10 \%(\mathrm{v} / \mathrm{v})$ of LES or FBS.

\section{Quantitative real time RT-PCR}

Total RNA was extracted by commercial kit Illustra RNAspin mini (GE Healthcare ${ }^{\circledast}$, Buckinghamshire, United
Kingdom) according to manufacturer's instructions and quantified by spectrophotometry in Nanodrop ND-1000 (Nanodrop Technologies, Inc., Wilmington, Delaware, EUA). cDNA synthesis was based on RNA by commercial Kit SuperScript ${ }^{\circledast}$ First Strand (Invitrogen ${ }^{\oplus}$, Carlsbad, California, USA) according to manufacturer's instructions. The cDNA concentration was determined by Qubit dsDNA BR Assays kit (Invitrogen ${ }^{\circledR}$, Carlsbad, California, USA), by Qubit 2.0 Fluorometer (Invitrogen ${ }^{\circledR}$, Carlsbad, California, USA). Gene expression evaluation of the target genes $B L G$ (primer BGL F: 5' GAAATTCGACAAAGCCCTCA 3'; BGL R: 5' GGCAGGGGCTCACCTAGAC 3; NCBI sequence NM_001009366.1) CSN1S1 (primer CSN1S1 F: 5' ACTTCTCATCCTTACCTGTCTT 3'; CSN1S1 R: 5' GGGCACATCTTCCTTTTGA 3'; NCBI sequence NM_001009795.1), CSN2 (primer CSN2 F: 5' ATCCAGGCCTTTCTGCTGT 3'; CSN2 R: 5' AAAGTGAGGAGGGGGCAT 3'; NCBI sequence NM_001009373.1), and the housekeeping genes Glyceraldehyde-3-phosphate dehydrogenase (GAPDH) (primer GAPDH F: 5' atgcctcctgcaccacca 3'; GAPDH R: 5' AGTCCCTCCACGATGCCAA 3'; NCBI Sequence NM_001190390.1) and beta-actin (ACTB) (primer ACTB F: 5' GTCCACCTTCCAGCAGATGT 3'; ACTB R: 5'GTCACCTTCACCGTTCCAGT 3'; NCBI Sequence NM_173979.3) was performed by quantitative real time RTPCR (Mastercycler Ep Realplex Thermal Cycler, Eppendorf AG, Hamburg, Germany). All primers were previously standardized and efficiency curve was performed with cDNA obtained from ovine mammary gland biopsy.

\section{Immunocytochemistry}

Approximately $2 \times 10^{4}$ cells from P12 were cultured over coverslips $(22 \times 22 \mathrm{~mm})$ with culture medium for 5 days in a 6-well plate. Coverslips were rinsed with $\mathrm{PBS}$; cells were then fixed with methanol for $10 \mathrm{~min}$ at $-20^{\circ} \mathrm{C}$ and permeabilized with $0.25 \%(\mathrm{v} / \mathrm{v})$ Triton X-100 solution for $10 \mathrm{~min}$ at room temperature. Antigenic sites were blocked with $1 \%(\mathrm{w} / \mathrm{v})$ bovine serum albumin (BSA) and 10\% (v/v) inactivated ovine serum solution for $30 \mathrm{~min}$ at $37^{\circ} \mathrm{C}$. Each microscope coverslip was incubated with mouse anti-vimentin antibody clone V9 (1:40; V-6630) or anti-cytokeratin antibody clone K8.13 (1:20; C-6909) overnight at $4^{\circ} \mathrm{C}$. After incubation, coverslips were rinsed with PBS, incubated with anti-mouse FITC-labeled IgG antibody (1:3,000 in PBS with 1\% (w/v) BSA) for $1 \mathrm{~h}$ at room temperature. All coverslips were rinsed with PBS and mounted with Vectashield ${ }^{\oplus}$ containing DAPI (VECTOR $\left.{ }^{\circledR}\right)$. 


\section{Cell growth rate after induction of differentiation}

Growth rate analysis was performed on P12 MED or MD derived cells cultured with FBS or LES, plated on 24 -well plates $\left(1 \times 10^{4}\right.$ cell/well), in triplicate. Viable cell proliferation was assessed with Trypan Blue staining after $24,48,96$, and $192 \mathrm{~h}$ of culture.

\section{Statistical analysis}

All data were analyzed using a $2 \times 2$ factorial design by the SAS 9.3 software (SAS Institute, Cary, NC), considering as factors: tissue dissociation method (MED and MD) and serum (FBS and LES). Data related to cell growth were obtained by linear regression analysis, using the slope as a measure of cell growth per hour. Through the PROC GLM we assessed the effects of serum, tissue dissociation method, and the interaction between these factors. Quantitative realtime RT-PCR data were analyzed using PROC MIXED, as described previously by Steibel et al. (2009). Cell culture replicate was also included in the model. Results in graphs are presented in $\log 2$ distribution; however, for ease of interpretation relative fold change is used in the text.

\section{Results}

\section{Establishment, culture, and morphologic characterization of MD and MED}

MD and MED cells were simultaneously cultured until P12 and displayed homogeneous growth since P3 based on the time to reach confluence. For passages 0,1 , and 2 the time to reach confluence was close to 15 days, but it was reduced to 10 days from $\mathrm{P} 3$ to $\mathrm{P} 5$. Time to reach confluence was 7 days from P5 to P10 in both groups. However, after $\mathrm{P} 10$, the time to reach confluence in MED cells increased to 17 days. Time to reach confluence in MD cells remained 7 days during the 8 months of cell culture (from P5 to P12).

Morphologic characteristics were observed every 48-72h during media change using inverted optical microscopy and differences between MED and MD cells were noticeable from $\mathrm{P} 4$. After MD, two cell populations with different morphologies were observed: one consisted of cell clusters with larger surface and another of slim cells with elongations (Figure 1A). Later at P12 cells were more heterogeneous, presenting epithelial morphology (Figure 1B). Nevertheless, MED group always showed higher number of slim cells (Figure 1C and D), apparently strongly adhered to the dish with fibroblastlike appearance (Figure 1D), which did not form cell clusters after P10. Only MD cells were positively stained for K8.13 (Figure 2A) and showed low vimentin staining similar to background (Figure 2B). However, cells from MED were negatively stained for K8.13 (Figure 2C) and were positively stained for vimentin at P12 (Figure 2D). In the MD group, epithelial-like cells were positive for K8.13 (Figure 2 A). However, in MED group elongated fibroblast-like cells were positive for vimentin at P12 (Figure 2D).
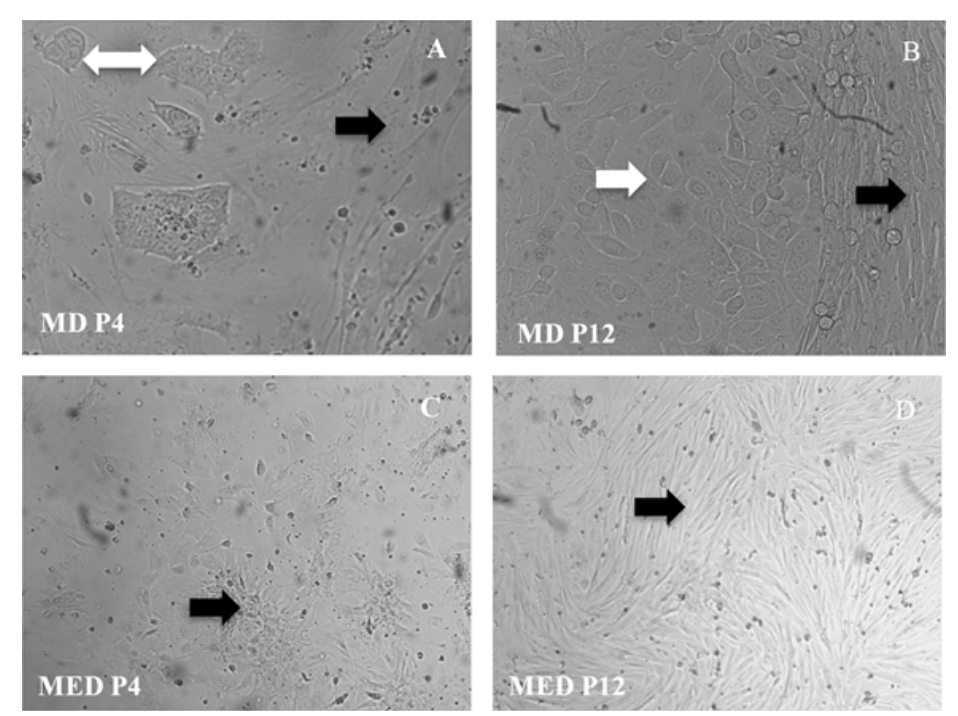

Figure 1 - Representative images at $400 \mathrm{X}$ magnification by Image Plus Software. A) MD (mechanical dissociation) at passage 4 (P4), B) MD at P12. C) MED (mechanical and enzymatic dissociation) at passage $4(\mathrm{P} 4), \mathrm{D}) \mathrm{MED}$ at P12. Black arrows indicate slim cells with elongations and white arrows indicate clustered cells 


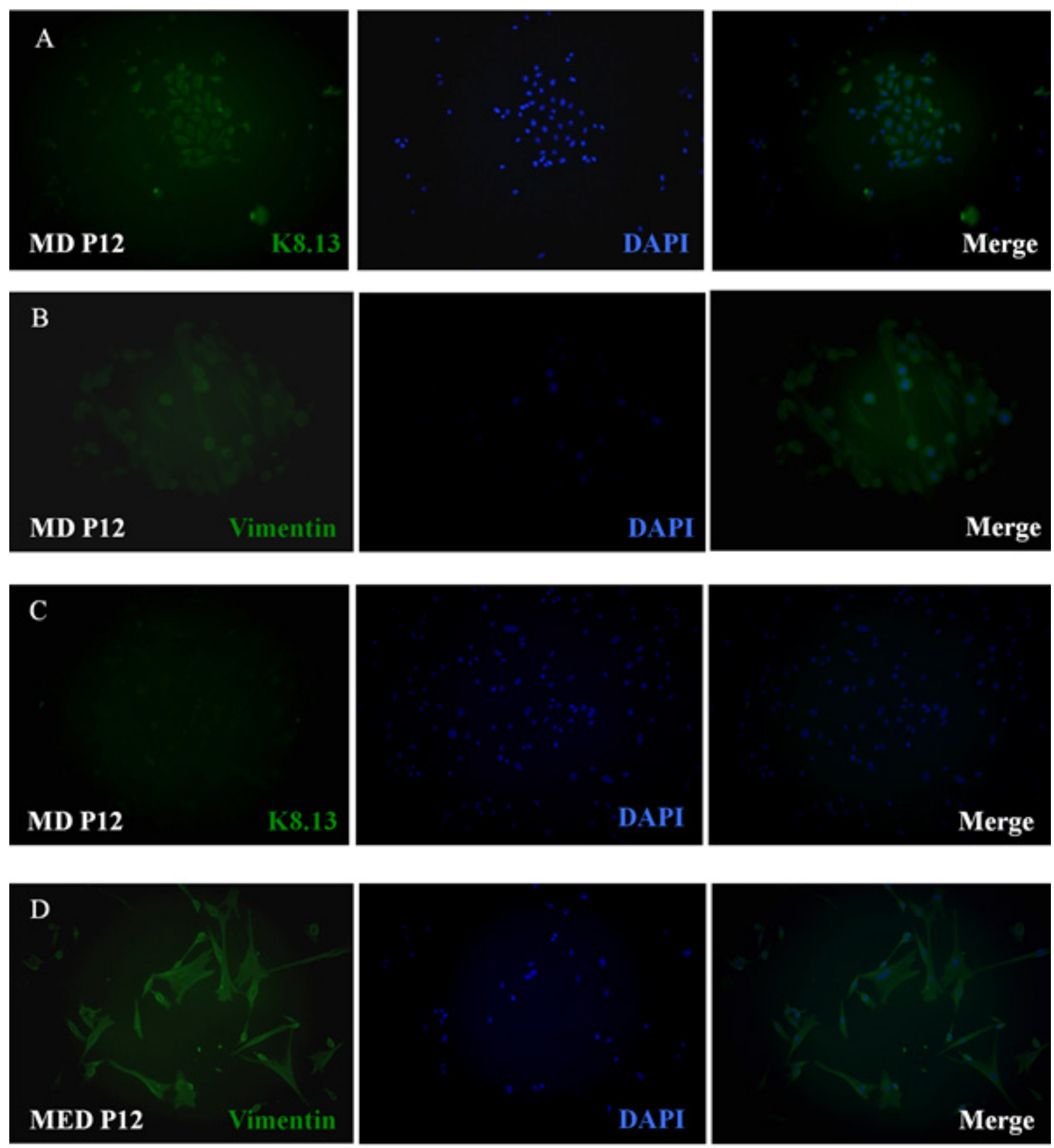

Figure 2 - Representative images at 400X magnification by Image Plus Software, images of immunocytochemetry with DAPI (blue brand cell nucleus) and secondary antibody/FITC (green) for vimentin and cytokeratin k8.13 (cytoplasmic intermediate filaments) at passage 12 (P12). (A) MD (mechanical dissociation) with epithelial-like cells positively stained for cytokeratin 8.13 (K 8.13) and DAPI, (B) MD low stained for presence of vimentin, cells nucleus stained with DAPI, (C) MED (mechanical and enzymatic dissociation) with cells negativaly stained for presence of K8.13 and cells nucleus stained with DAPI and (D) MED with cells positively stained for presence of vimentin and cells nucleus stained with DAPI

Table 1 - Effect of medium (FBS, fetal bovine serum or LES, lactating ewe serum) or mammary cell type (MD, mechanical dissociation or MED, mechanical and enzymatic dissociationon total of viable cells. Variables (mean \pm S.E.M) and Pvalue. Significance level of $0.05, \mathrm{n}=12$

\begin{tabular}{|c|c|c|c|c|c|c|c|c|}
\hline & \multicolumn{2}{|c|}{ FBS } & \multicolumn{2}{|c|}{ LES } & \multirow[t]{2}{*}{ Std Dev } & \multicolumn{3}{|c|}{$P$ value } \\
\hline & MD & MED & MD & MED & & Medium & Cell type & Medium*cell type \\
\hline $\begin{array}{c}\text { Total of } \\
\text { viable cells }\end{array}$ & $0.456 \times 10^{6}$ & $0.423 \times \times 10^{6}$ & $0.433 \times 10^{6}$ & $0.263 \times 10^{6}$ & 22.82 & 0.026 & 0.0111 & 0.0753 \\
\hline
\end{tabular}




\section{MED and MD viability after differentiation induction}

The number of viable cells/well was assessed for MD and MED cells cultured with LES or FBS. Serum $(\mathrm{P}=0.026)$ and tissue dissociation method $(\mathrm{P}=0.011)$ effects were observed on total number of viable cells/well, but not their interaction $(\mathrm{P}=0.075)$ (Table 1$)$.

\section{Cell growth rate with differentiation induction}

Total number of viable cells in each triplicate was evaluated 24, 48, 96, and $192 \mathrm{~h}$ after differentiation induction at P12. To evaluate the rate of cell growth the number of new cells per hour was determined and we observed an effect of serum on cell growth rate for MD
$(\mathrm{P}=0.0008$ ) but not for MED cells (Figure 3 ). There was an effect of tissue dissociation method with cells cultured with FBS $(\mathrm{P}=0.0016)$ but not with LES (Figure 3).

\section{Quantitative real-time RT-PCR}

$B L G$ and CSN2 expressions were observed in cell samples from all groups; however, CSN1S1 was never detected. Serum and tissue dissociation method did not affect $B L G$ (Figure $4 \mathrm{~A}$ ). CSN2 was more expressed in $\mathrm{MD}$, when they are treated with $10 \% \mathrm{SFB}$ medium ( $\mathrm{P}=$ 0.021 ) with a reduction of 3.21-foldin (Figure 4B), than in MED. Effect of serum type (SFB or LES) was observed in MD cells $(\mathrm{P}=0.019)$ with a fold reduction of 3.6 for LES (Figure 4B).

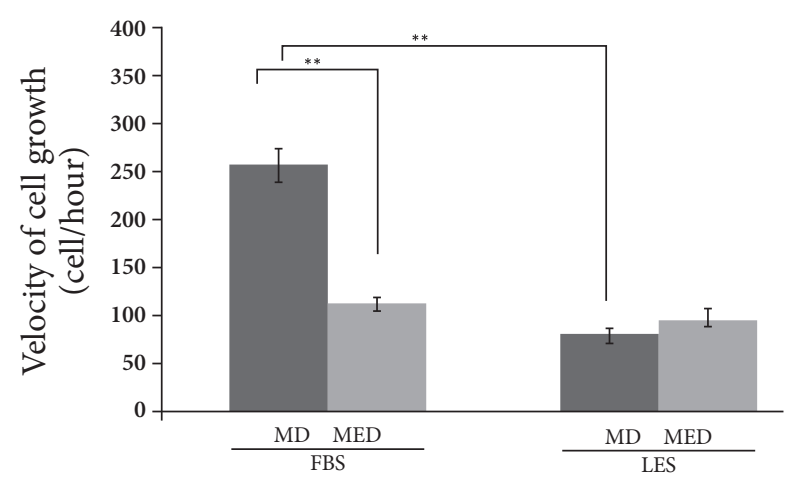

Significant difference $\left({ }^{* *} \mathrm{P}<0,01\right)$

Figure 3 - Effect of medium (FBS, fetal bovine serum or LES, lactating ewe serum) or mammary cell type (MD, mechanical dissociation or MED, mechanical and enzymatic dissociation, B) on cell velocity growth (cell/hour), ${ }^{* *} \mathrm{P} \leq 0.01, \mathrm{n}=12$

(A)

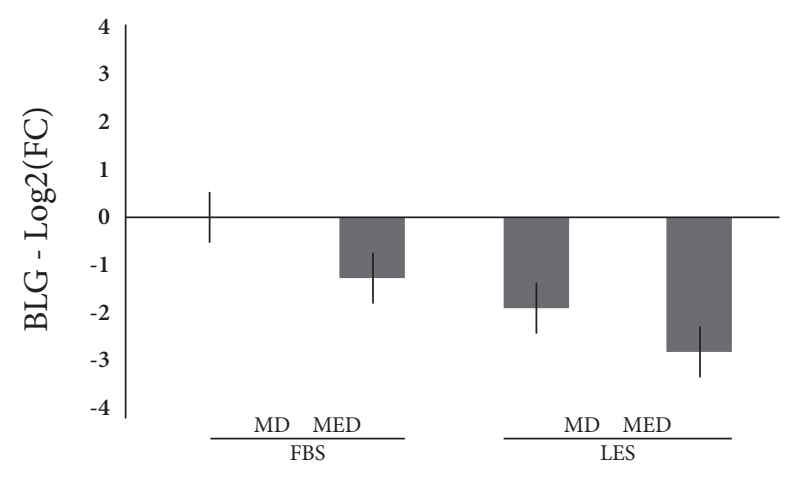

(B)

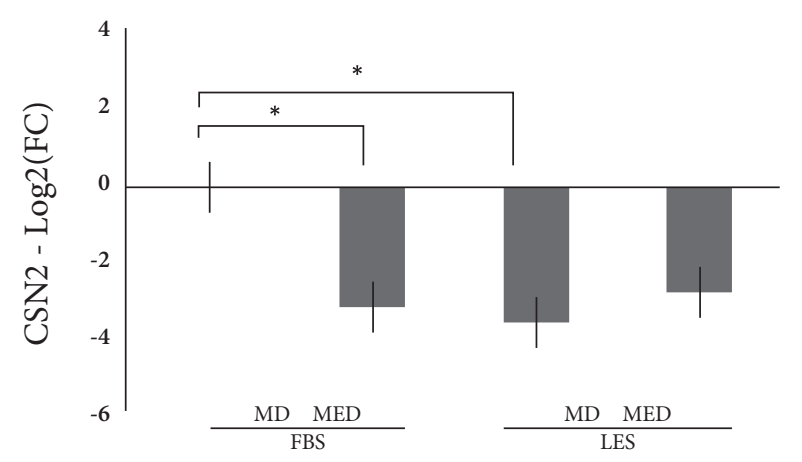

Significant difference $\left({ }^{*} \mathrm{P}<0,05\right)$

Figure 4-Quantification of milk protein genes of ovine mammary cells (MD and MED) cultured with SFB or LES medium. A) Relative expression of $B L G$. B) Relative expression of CSN2. Values are presented as $\log 2$ (FC) \pm Ct standard deviation. Asterisks indicate significant statistical difference $\left({ }^{*} \mathrm{P} \leq 0.05 ;\right) ; \mathrm{n}=12$ 


\section{Discussion}

In this study we evaluated the effect of MD or MED on long-term ovine mammary cell culture heterogeneity and milk proteins' gene expression, as well as the use of LES or SFB as inductor factor for milk proteins' mRNA expression. To our knowledge this is the first time the establishment of ovine mammary epithelial cell culture without any previous enzymatic digestion is reported. Morevover, these cells were able to express mRNA of milk proteins (BLG and CSN2).

Our findings showed that MD cells cultured with FBS had two morphological cell types, and the highest relative expression of CSN2. On the other hand, MED cells cultured with SFB had predominantly overriding fibroblast-like cells with positive staining for vimentin and low relative expression of CSN2. CSN2 and BLG were expressed in different levels in MD and MED, suggesting that they had different proportions of mammary epithelial cells, which are responsible for milk protein expression. We also showed that the total number of viable cells after differentiation was higher for MD than for MED. Thus, here we observed that tissue disaggregation method acted on long-term mammary cell culture heterogeneity and rate of cell growth.

For instance, an interesting study (PEI et al., 2004) speculated that enzymatic disaggregation methods in mice provide a large number of isolated cells from mammary tumors, but most of these cells are unable to attach and fibroblast outgrowth happens in a long-term culture. This supposition was well supported by our observation that MD and MED cells had different morphology from passages as early as $\mathrm{P} 4$.

We showed that the mRNA expression profiles were different for CSN2 and BLG.We observed a positive effect of SFB in CSN2 mRNA relative expression, and this fact agrees with our postulation that SFB contains lactogenic factors that promote CSN2 transcription. This supposition is well supported by SFB composition. Among the factors currently identified in SFB, some of them have a lactogenic action regulating milk protein transcription. IGF-I, insulin, and growth hormone are described in SFB composition (REYNOLDS et al., 1990; SINGH, ARMSTRONG, 1997). Insulin, hydrocortisone, and prolactin are required in rodents for induction of CSN2 gene expression (BOLANDER et al., 1981; NAGAIAH et al., 1981; KULSKI et al., 1983). However, insulin is essential for CSN2 transcription, but not for transcript stabilization (CHOMCZYNSKI et al., 1984).

Insulin and prolactin act synergistically in CSN2 mRNA translation (CHOI; MASON, 2000). These two factors have a key role in phospharilation of Stat5, which stimulates CSN2 transcription in mammary cell culture in mice (WHEELER et al., 2001). In bovines, GH and IGF-I stimulate Stat 5 binding activity (YANG et al., 2000). Thus, we propose that SFB contains lactogenic factors such as insulin, IGF-I, and GH that increase CSN2 transcription by ovine mammary epithelial cells, stimulating Stat 5 binding activity. Futures studies are necessary to establish the presence and the functionality of Stat 5 binding activity in $\mathrm{MD}$ and MED.

$B L G$ expression was observed in all treatments but was not affected by medium or disaggregation method. Insulin, cortisol, and prolactin are required for $B L G$ mRNA synthesis because ewe mammary explants are highly expressed until $8 \mathrm{~h}$ after the induction and, $8 \mathrm{~h}$ later, the $B L G$ mRNA expression declines 75\% (OSBORNE et al., 1995). In addition, the mRNA synthesis cannot be restored by a new stimulation with lactogenic hormones (WHEELER et al., 1995a). Therefore, in this study we believe that $B L G$ mRNA analysis was performed after the BLG mRNA peak expression (after 7 days of continuous treatment with SFB or LES).

We also increased growth rate of both cell cultures in P12 with addition of FBS or LES in culture medium. We observed effects of medium and cell type on growth rate and the MD/SFB group had the highest cell proliferation. This fact agrees with our supposition that SFB provides a positive environment for mammary cell proliferation. Our results suggested medium supplemented with LES did not correctlly provide all factors necessary for cell proliferation or mammary cell differentiation and milk secretion, and consecutively we observed a low milk protein expression in that treatment. For instance, other study described that FBS strongly stimulates bovine mammary cell proliferation and evaluation of doubling time suggested that $10 \%$ of FBS is the optimal concentration in growth media (HU et al., 2009). Our study supports the theory that $10 \%$ FBS is the optimal concentration for mammary epithelial cell growth media (GERMAN; BARASH, 2002; HU et al., 2009).

Results obtained in this study showed that enzymatic digestion of mammary parenchyma fragments changed cell culture characteristics and the expression of milk 
proteins' mRNA in a detrimental manner when compared to mechanical dissociation.

\section{Conclusion}

Method of dissociation influenced the outcome of ovine mammary cell culture. Mechanic disaggregation method was more effective than enzymatic digestion to establish mammary epithelial cell culture. MD cultured with $10 \%$ of FBS media was the most efficient method for culture and induced differentiation of ovine mammaryepithelial cells.

\section{References}

BOLANDER, F. F; NICHOLAS, K. R.; VAN WYK, J. J.; TOPPER, Y. J. Insulin is essential for accumulation of casein mRNA in mouse mammary epithelial cells. Proceedings of the National Academy of Sciences of the United States of America, v. 78, n. 9, p. 5682-5684, 1981.

CHOI, S. W.; MASON, J. B. Folate and carcinogenesis: an integrated scheme. Journal of Nutrition, v. 130, n. 2, p. 129-132, 2000.

CHOMCZYNSKI, P.; QASBA, P.; TOPPER, Y. J. Essential role of insulin in transcription of the rat 25,000 molecular weight casein gene. Science, v. 226, n. 4680, p. 1326-1328, 1984. doi: 10.1126/science.6390680.

DÜCHLER, M.; SCHMOLL, F; PFNEISL, F. BREM, G. SCHELLANDER, K. Omec II: a new ovine mammary epithelial cell line. Biology of the Cell, v. 90, n. 2, p. 199205, 1998. doi: 10.1016/S0248-4900(98)80340-7.

FRESHNEY, R. I. Culture of animal cells: a manual of basic technique. New York, NY: Wiley-Liss Inc., 1994.

GERMAN, T.; BARASH, I. Characterization of an epithelial cell line from bovine mammary gland. In Vitro Cellular \& Developmental Biology - Animal, v. 38, n. 5, p. 282-292, 2002. doi: 10.1290/1071-2690(2002)038<0282:COAECL $>2.0 . C O ; 2$.

GREEN, M. R.; PASTEWKA, J. V. Characterization of major milk proteins from BALB/c and $\mathrm{C} 3 \mathrm{H}$ mice. Jornal of Dairy Science, v. 59, n. 2, p. 207-215, 1976. doi: 10.3168/ jds.S0022-0302(76)84186-0.

\section{Conflict of Interest}

The authors declare that there is no conflict of interest that could be perceived as jeopardizing the impartiality of the research.

\section{Acknowledgement}

Funding: This research was supported by São Paulo Research Foundation (FAPESP), grant 2008/56138-2, and by the National Counsel of Technological and Scientific Development (CNPq). Prof. Dr. Marcilio Nichi ran the statistical analysis.

HU, H.; WANG, J.; BU, D.; WEI, H.; ZHOU, L.; LI, F.; LOOR, J. J. In vitro culture and characterization of a mammary epithelial cell line from Chinese Holstein dairy cow. PLoS One, v. 4, n. 11, p. e7636, 2009. doi: 10.1371/ journal.pone.0007636.

ILAN, N.; BARASH, I.; GOOTWINE, E.; SHANI, M. Establishment and initial characterization of the ovine mammary epithelial cell line nish. In Vitro Cellular \& Developmental Biology - Animal, v. 34, n. 14, p. 326-332, 1998. doi: 10.1007/s11626-998-0009-x.

JENNESS, R.; SLOAN, R. E. The composition of milks of various species: a review. Dairy Science Abstracts, v. 32, n. 10, p. 599-612, 1970.

KULSKI, J. K.; NICHOLAS, K. R.; TOPPER, Y. J.; QASBA, P. Essentiality of insulin and prolactin for accumulation of rat casein mRNAs. Biochemical and Biophysical Research Communications, v. 116, n. 3, p. 994-999, 1983. doi: 10.1016/S0006-291X(83)80240-X.

LAMMERS, A.; NUIJTEN, P. J.; KRUIJT, E.; STOCKHOFE-ZURWIEDEN, N.; VECHT, U.; SMITH, H. E.; VAN ZIJDERVELD, F. G. Cell tropism of Staphylococcus aureus in bovine mammary gland cell cultures. Veterinary Microbiology, v. 67, n. 2, p. 77-89, 1999.

MATITASHVILI, E.; BAUMAN, D. E. Culture of primary bovine mammary epithelial cells. In Vitro Cellular \& Developmental Biology - Animal, v. 35, n. 8, p. 431-434, 1999. doi: 10.1007/s11626-999-0048-y. 
NAGAIAH, K.; BOLANDER JR, F. F.; NICHOLAS, K, R.; TAKEMOTO, T.; TOPPER, Y. J. Prolactin-induced accumulation of casein mRNA in mouse mammary explants: a selective role of glucocorticoid. Biochemical and Biophysical Research Communications, v. 98, n. 2, p. 380-387, 1981. doi: 10.1016/0006-291X(81)90851-2.

OSBORNE, R. HOWELL, M.; CLARK, A. J.; NICHOLAS, K. R. Hormone-dependent expression of the ovine betalactoglobulin gene. Journal of Dairy Research, v. 62, n. 2, p. 321-329, 1995.

PARK, Y. W.; JUÁREZ, M.; RAMOS, M.; G. F. W. HAENLEIN. Physico-chemical characteristics of goat and sheep milk. Small Ruminant Research, v. 68, n. 1-2, p. $88-113,2007$.

PEI, X. F.; NOBLE, M. S.; DAVOLI, M. A.; RODFJORD, E.; TILlI, M. T.; FURTH, P. A.; RUSSELL, R.; JOHNSON, M. D.; DICKSON, R. B. Explant-cell culture of primary mammary tumors from MMTV-c-Myc transgenic mice. In Vitro Cellular \& Developmental Biology - Animal, v. 40, n. 1-2, p. 14-21, 2004. doi: 10.1290/1543-706X(2004)40<14:ECOPMT>2.0.CO;2.

REYNOLDS, L. P.; FERRELL, C. L.; ROBERTSON, D. A.; KLINDT, J. Growth hormone, insulin and glucose concentrations in bovine fetal and maternal plasmas at several stages of gestation. Journal of Animal Science, v. 68, n. 3, p. 725-733, 1990. doi: 10.2527/1990.683725x.

ROSE, M. T.; ASO, H.; YONEKURA, S.; KOMATSU, T.; HAGINO, A; OZUTSUMI, K.; OBARA, Y. In vitro differentiation of a cloned bovine mammary epithelial cell.
Journal of Dairy Research, v. 69, n. 3, p. 345-355, 2002. doi: 10.1017/S0022029902005551.

SINGH, B.; ARMSTRONG, D. T. Insulin-like growth factor-1, a component of serum that enables porcine cumulus cells to expand in response to follicle-stimulating hormone in vitro. Biology of Reproduction, v. 56, n. 6, p. 1370-1375, 1997. doi: 10.1095/biolreprod56.6.1370.

SUN, Y. L.; LIN, C. S.; CHOU, Y. C. Establishment and characterization of a spontaneously immortalized porcine mammary epithelial cell line. Cell Biology International, v. 30, n. 12, p. 970-976, 2006. doi: 10.1016/j. cellbi.2006.06.023.

WHEELER, T. T.; BROADHURST, M. K.; SADOWSKI, H. B.; FARR, V. C.; PROSSER, C. G. Stat5 phosphorylation status and DNA-binding activity in the bovine and murine mammary glands. Molecular and Cellular Endocrinology, v. 176, n. 1-2, p. 39-48, 2001. doi: 10.1016/ S0303-7207(01)00481-6.

WHEELER, T. T.; CALLAGHAN, M. R.; DAVIS, S. R.; PROSSER, C. G.; WILKINS, R. J. Milk protein synthesis, gene expression, and hormonal responsiveness in primary cultures of mammary cells from lactating sheep. Experimental Cell Research, v. 217, n. 2, p. 346-354, 1995. doi: 10.1006/excr.1995.1096.

YANG, J.; KENNELLY, J. J.; BARACOS, V. E. The activity of transcription factor Stat 5 responds to prolactin, growth hormone, and IGF-I in rat and bovine mammary explant culture. Journal of Animal Science, v. 78, n. 12, p. 31143125, 2000. doi: 10.2527/2000.78123114x. 